\title{
Pengaruh Menit Pertandingan Sepakbola dengan Tingkat Kebisingan di Stadion Gelora Sriwijaya Jakabaring Palembang (Studi Kasus: Pertandingan SFC Vs PS Tira)
}

\author{
Jumingin $^{1 *}$, Andi Arif Setiawan ${ }^{1}$, Hartono ${ }^{1}$ \\ e-mail: juminginpgri@gmail.com \\ ${ }^{1}$ Program Studi Fisika, Fakultas MIPA Universitas PGRI Palembang
}

\begin{abstract}
Research has been conducted on the effect of the minute soccer matches to the noise level at the Jakabaring Sriwijaya Stadium in Palembang, during the FC Sriwijaya match against PS Tira. The purpose of this study was to determine the effect of minutes of soccer matches on the noise level. The research method used was purposive sampling with direct measurements at the Jakabaring Sriwijaya Stadium in Palembang, during the SFC match against PS Tira. Noise level measurements were carried out in the West stands, East stands, North stands and South stand, on 15 minutes before the match, 10 minutes, 25 minutes, 40 minutes, breaks, 55 minutes, 70 minutes, and 85 th minute. The data obtained were analyzed using analysis of variance one factorial (minutes of match). From the measurement results obtained the lowest noise level of $73.95 \mathrm{~dB}$ at 15 minutes before the match and the highest noise level of $82.85 \mathrm{~dB}$ at 40 minutes. From the analysis of variance with $(\alpha=5 \%)$ shows the real effect of minutes of the match with the level of noise generated.
\end{abstract}

Keywords: Match Minutes, Noise Level, Jakabaring Sriwijaya Stadium.

\begin{abstract}
ABSTRAK
Telah dilakukan penelitian tentang pengaruh menit pertandingan Sepakbola dengan tingkat kebisingan di Stadion Gelora Sriwijaya Jakabaring Palembang, pada saat pertandingan Sriwijaya FC melawan PS Tira. Tujuan dari penelitian ini adalah untuk mengetahui pengaruh menit pertandingan sepakbola dengan tingkat kebisingan yang ditimbulkan. Metode penelitian yang digunakan adalah purpossive sampling dengan pengukuran langsung di stadion Gelora Sriwijaya Jakabaring Palembang, pada saat pertandingan SFC melawan PS Tira. Pengukuran tingkat kebisingan dilakukan pada tribun Barat, Tribun Timur, Tribun Utara dan Tribun Selatan, pada 15 menit sebelum pertandingan, menit ke-10, menit ke-25, menit ke-40, istirahat, menit ke-55, menit ke70, dan menit ke-85. Data yang diperoleh dianalisis dengan menggunakan analisis sidik ragam satu faktorial (menit pertandingan). Dari hasil pengukuran diperoleh tingkat kebisingan terendah sebesar 73,95 dB pada 15 menit sebelum pertandingan dan tingkat kebisingan tertinggi sebesar $82,85 \mathrm{~dB}$ pada menit-40. Dari analisis sidik ragam dengan $(\alpha=5 \%)$ menunjukkan adanya pengaruh yang nyata menit pertandingan dengan tingkat kebisingan yang ditimbulkan.
\end{abstract}

Kata Kunci: Menit Pertandingan, Tingkat Kebisingan, Gelora Sriwijaya Jakabaring.

\section{PENDAHULUAN}

Pertandingan sepakbola di Indonesia menjadi hiburan tersendiri bagi sebagian masyarakat, terutama para penggemar sepakbola dan kelompok suporter. Di kota Palembang sendiri pada 
saat ini memiliki klub sepakbola yang menjadi kebanggaan masyarakat Sumatera Selatan umumnya dan khususnya masyarakat kota Palembang yaitu Sriwijaya Football Club (SFC). Setiap ada jadwal pertandingan kandang yang dijalani tim SFC, masyarakat berbondong-bondong datang untuk menyaksikan pertandingan yang dilangsungkan terutama kelompok suporter setia SFC. Kelompok suporter SFC adalah Sriwijaya mania, Singa mania, dan Ultras Palembang.

Hadirnya kelompok suporter SFC dan masyarakat umum ke stadion tentunya akan berdampak pada muncul bunyi/suara baik sebelum pertandingan, pada saat pertandingan, maupun setelah pertandingan selesai. Bunyi/suara yang ditimbulkan ini tentunya akan menimbulkan tingkat kebisingan yang berbeda-beda, baik sebelum pertandingan, pada saat pertandingan, maupun setelah pertandingan selesai. Pada saat ada pertandingan, sebagian kelompok suporter akan membawa berbagai atribut pertandingan termasuk seperti alat musik (drum, terompet, dan sebagainya). Selain itu juga sumber bunyi lain yang ada dalam stadion, misalnya suara penonton, tepuk tangan, bunyi peluit dan bunyi mikrofon panitia pertandingan.

Pada saat pertandingan berlangsung kemungkinan akan terjadi penambahan atau pengurangan jumlah penonton, hal ini jelas bahwa penambahan atau pengurangan jumlah penonton berpengaruh terhadap tingkat kebisingan. Menurut Adnan (2006), aktivitas mahasiswa di ruang kelas dan di luar kelas berpengaruh terhadap kebisingan di kedua tempat tersebut. Adanya peningkatan volume kendaraan pada daerah traffic light dapat menyebabkan adanya peningkatan kebisingan (Jumingin dan Ramadhani, 2018). Rata-rata banyaknya jumlah kendaraan yang melintas berpengaruh terhadap kebisingan yang ditimbulkan (Wafiroh, 2013).
Jumlah suporter dan penonton terus mengalami penambahan sejak kick off pertandingan dimulai. Menjelang akhir pertandingan, sebagian penonton ada yang meninggalkan stadion yang menyebabkan adanya pengurangan jumlah pertandingan. Disamping itu, pada menit-menit pertandingan berlangsung akan terjadinya perubahan bunyi yang ditimbulkan. Selama aktivitas pertandingan berlangsung akan terjadi fluktuasi kebisingan akibat perubahan suara. Misalnya pada saat terjadi gol bagi SFC maka penonton dan suporter tuan rumah akan bersorak, sehingga kebisingan yang muncul akan tinggi.

Berdasarkan uraian di atas maka perlu dilakukan pengukuran tingkat kebisingan pada menit-menit pertandingan selama pertandingan berlansung. Penelitian ini bertujuan untuk mengetahui pengaruh menit pertandingan sepakbola terhadap hasil pengukuran tingkat kebisingan yang ditimbulkan.

\section{BAHAN DAN METODE}

Penelitian ini dilakukan di Stadion Gelora Sriwijaya Jakabaring Palembang, pada saat pertandingan SFC melawan PS Tira. Pengukuran dilakukan pada tribun Barat, Timur, Utara, dan Selatan. Alat-alat yang digunakan dalam penelitian ini adalah Sound Level Meter merk Luxtron (tipe S1-4010), stopwatch, tripod, dan alat tulis. Penelitian ini menggunakan metode Purpossive Sampling, dengan pengukuran langsung di stadion Gelora Sriwijaya Jakabaring Palembang pada saat pertandingan SFC melawan PS Tira. Sound level meter yang digunakan untuk mengukur tingkat kebisingan diletakkan pada ketinggian 1,5 meter di atas permukaan lantai di masing-masing tribun penonton. Pengukuran dilakukan pada 15 menit sebelum pertandingan, menit ke-10, menit ke-25, menit ke-40, istirahat, menit ke-55, menit ke-70, dan menit ke-85. Pengukuran dilakukan selama 10 menit 
dimasing-masing tribun dan menit pengukuran, dengan pembacaan setiap 5 detik (KepMen LH, 1996).

Dari data yang diperoleh kemudian dihitung nilai rata-ratanya untuk masingmasing pengukuran. Kemudian untuk mengetahui pengaruh menit pertandingan sepakbola terhadap hasil pengukuran tingkat kebisingan yang ditimbulkan, dilakukan analisis sidik ragam uji $\mathrm{F}$ satu faktorial yaitu menit pertandingan. Jika menit pertandingan berpengaruh terhadap tingkat kebisingan, maka dilakukan uji lanjut beda nyata terkecil dengan $\alpha=1 \%$ untuk mengetahui menit ke berapa yang berpengaruh sangat nyata terhadap tingkat kebisingan yang timbul.

\section{HASIL DAN PEMBAHASAN}

Hasil pengukuran tingkat
kebisingan rata-rata pada saat
pertandingan SFC melawan PS Tira di
Stadion Gelora Sriwijaya Jakabaring
Palembang tribun Barat, Timur, Utara dan
Selatan pada 15 menit sebelum
pertandingan, menit ke-10, menit ke-25,
menit ke-40, istirahat, menit ke-55, menit
ke-70, dan menit ke-85 disajikan dalam
Tabel 1 berikut:

Tabel 1. Tingkat Kebisingan Rata-Rata pada saat pertandingan SFC melawan PS Tira di Stadion Gelora Sriwijaya Jakabaring Palembang tribun Barat, Timur, Utara dan Selatan pada 15 menit sebelum pertandingan (sebagai kontrol), menit ke-10, menit ke25, menit ke-40, istirahat, menit ke-55, menit ke-70, dan menit ke-85.

\begin{tabular}{|c|c|c|c|c|}
\hline Menit pertandingan & $\begin{array}{c}\text { Tingkat Kebisingan } \\
\text { Rata-rata (dB) }\end{array}$ & $\mathbf{F}_{\text {tabel }}$ & F $_{\text {hitung }}$ & Sig. $(\alpha)$ \\
\hline 15 menit sebelum pertandingan & 73,95 & \multirow{8}{*}{2,240} & \multirow{8}{*}{3,462} & \multirow{8}{*}{0,010} \\
\hline Menit ke-10 & 77,65 & & & \\
\hline Menit ke-25 & 79,43 & & & \\
\hline Menit ke-40 & 82,85 & & & \\
\hline Istirahat & 77,48 & & & \\
\hline Menit ke-55 & 82,13 & & & \\
\hline Menit ke-70 & 82,63 & & & \\
\hline Menit ke-85 & 82,05 & & & \\
\hline
\end{tabular}

Dari Tabel 1 di atas terlihat bahwa tingkat kebisingan tertinggi adalah $82,85 \mathrm{~dB}$ pada pertandingan menit ke-40, sedangkan tingkat kebisingan terendah adalah $73,95 \mathrm{~dB}$ pada saat 15 menit sebelum pertandingan.

Dari tabel 1 terlihat bahwa tingkat kebisingan rata-rata sebelum pertandingan dan pada waktu istirahat (jedah babak I dan babak II) menunjukkan tingkat kebisingan rata-rata yang lebih rendah dibandingkan dengan tingkat kebisingan rata-rata menit-menit pertandingan lainnya. Hal ini terjadi karena jumlah penonton yang hadir menjelang pertandingan dimulai belum begitu banyak dan pada waktu istirahat sebagian penonton keluar sejenak dari tribun penonton, sedangkan kelompok suporter tidak membunyikan alat musik dan cenderung beristirahat sehingga jumlah sumber bunyi berkurang dan volume bunyi yang dihasilkan juga tidak begitu tinggi.

Dengan berkurangnya jumlah sumber bunyi dan volume bunyi yang dihasilkan, maka tingkat kebisingan juga semakin rendah. Menurut Boediningsih (2011), bahwa kepadatan lalu lintas dapat menimbulkan kebisingan. Faktor tingginya tingkat kebisingan dipengaruhi oleh padatnya jumlah pengunjung dan keluar masuknya kendaraan ke dalam terminal (Ferial et al, 2016).

Sedangkan dimenit-menit pertandingan yang lain, tingkat kebisingan 
yang timbul lebih tinggi daripada waktu sebelum pertandingan dan pada saat istirahat. Hal ini terjadi karena adanya peningkatan jumlah penonton dan peningkatan volume bunyi/suara, baik dari dentuman alat musik, terompet, teriakan/sorak sorai penonton ditambah lagi suara peluit. Misalnya pada waktu terjadinya gol ataupun adanya kemelut digawang tim tamu, maka penonton dan suporter akan berteriak, bertepuk tangan dan ditambah bunyi peluit.

Dari Tabel 1 menunjukkan bahwa nilai $F_{\text {hitung }}$ sebesar 3,462 lebih besar daripada nilai $F_{\text {tabel }}$ sebesar 2,240 dengan nilai signifikansi 0,010 lebih kecil daripada $\alpha=5 \%$, hal ini menunjukkan bahwa menit pertandingan selama kegiatan pertandingan dihelat berpengaruh nyata terhadap timbulnya tingkat kebisingan di dalam stadion Gelora Sriwijaya Jakabaring Palembang pada saat pertandingan tim SFC melawan PS Tira.

Untuk mengetahui menit pertandingan yang berpengaruh sangat nyata terhadap tingkat kebisingan pada menit pertandingan yang lain, perlu dilakukan uji lanjut yaitu uji beda nyata tekecil (BNT) $\alpha=1 \%$. Hasil Uji BNT menit pertandingan terhadap tingkat kebisingan pada saat pertandingan tim SFC melawan PS Tira di Stadion Gelora Sriwijaya Jakabaring Palembang, disajikan dalam Tabel 2 berikut:

Tabel 2. Hasil Uji BNT menit pertandingan terhadap tingkat kebisingan pada saat pertandingan tim SFC melawan PS Tira di Stadion Gelora Sriwijaya Jakabaring Palembang $(\alpha=1 \%)$

\begin{tabular}{ccccccccc}
\hline \multirow{2}{*}{$\begin{array}{c}\text { Menit } \\
\text { Pertandingan }\end{array}$} & 1 & 2 & 3 & 4 & 5 & 6 & 7 & 8 \\
\cline { 2 - 9 } & & 0,142 & 0,034 & $0,001^{*}$ & 0,161 & $0,003^{*}$ & $0,002^{*}$ & $0,003^{*}$ \\
\hline 1 & 0,142 & & 0,473 & 0,044 & 0,943 & 0,079 & 0,052 & 0,084 \\
\hline 2 & 0,034 & 0,473 & & 0,176 & 0,431 & 0,279 & 0,202 & 0,292 \\
\hline 3 & $0,001^{*}$ & 0,044 & 0,176 & & 0,038 & 0,776 & 0,935 & 0,753 \\
\hline 4 & 0,161 & 0,943 & 0,431 & 0,038 & & 0,068 & 0,045 & 0,073 \\
\hline 5 & $0,003^{*}$ & 0,079 & 0,279 & 0,776 & 0,068 & & 0,839 & 0,976 \\
\hline 6 & $0,002^{*}$ & 0,052 & 0,202 & 0,935 & 0,045 & 0,839 & & 0,815 \\
\hline 7 & $0,003^{*}$ & 0,084 & 0,292 & 0,753 & 0,073 & 0,976 & 0,815 & \\
\hline 8 & & & & & & & &
\end{tabular}

*Berbeda sangat nyata

1 : Pengukuran 15 menit sebelum pertandingan

3 : Pengukuran pada menit ke-25

5 : Pengukuran pada waktu istirahat

7 : Pengukuran pada menit ke-70

2 : Pengukuran pada menit ke-10

4 : Pengukuran pada menit ke-40

6 : Pengukuran pada menit ke-55

8 : Pengukuran pada menit ke- 85

Dari Tabel 2 terlihat bahwa pengukuran tingkat kebisingan pada 15 menit sebelum pertandingan berbeda sangat nyata dengan pengukuran pada menit ke-40, menit ke-55, menit ke-70 dan menit ke-85. Hal ini karena kondisi sebelum pertandingan baik jumlah sumber bunyi (penonton), sorak sorai, bunyi dari alat musik yang dibawa suporter masih sedikit jika dibandingkan dengan menit ke-40, menit ke-55, menit ke-70 dan menit ke-85. Adanya penambahan jumlah kendaraan yang berkumpul di pertigaan menyebabkan tingkat kebisingan cenderung lebih tinggi (Ramli et al, 2014).

Sedangkan pengukuran tingkat kebisingan pada 15 menit sebelum pertandingan berbeda tidak sangat nyata tingkat kebisingan pada menit ke-10, menit ke-25 dan waktu istirahat. Kondisi sebelum pertandingan dengan awal pertandingan dan waktu istirahat hampir 
sama, walaupun ada penambahan jumlah penonton namun belum banyak. Bahkan pada saat istirahat banyak penonton yang hanya duduk santai dan sebagian lagi ada yang keluar sejenak dari tribun stadion.

Hasil pengukuran tingkat kebisingan berbeda tidak sangat nyata pada menit ke-10, menit ke-25, menit ke40, waktu istirahat, pada menit ke-55, menit ke-70 dan menit ke-85.

\section{KESIMPULAN}

Dari penelitian yang telah dilakukan dapat disimpulkan bahwa menit pertandingan berpengaruh terhadap hasil pengukuran tingkat kebisingan. Hasil pengukuran tingkat kebisingan sebelum pertandingan berbeda sangat nyata dengan tingkat kebisingan pada menit ke-40, menit ke-55, menit ke-70 dan menit ke-85. Sedangkan tingkat kebisingan pada 15 menit sebelum pertandingan berbeda tidak sangat nyata tingkat kebisingan pada menit ke-10, menit ke-25 dan waktu istirahat.

\section{DAFTAR PUSTAKA}

Adnan, Y. (2006). The Measurement of Noise Level Intensity at Indralaya Campus. Jurnal Penelitian Sains (19), 6-15.

Boediningsih, W. (2011). Dampak Kepadatan Lalu Lintas terhadap Polusi Udara Kota Surabaya. Jurnal Fakultas Hukum: XX (20), 119 138.

Ferial, L., Susanto, E., \& Silalahi, M. D. (2016). Analisis Tingkat Kebisingan Di Terminal Pakupatan (Kabupaten Serang, Provinsi Banten). Indonesian Journal of Urban and Environmental Technology, 8(1), 81-96.
Jumingin, J., \& Ramadhani, M. (2018). Analisis Faktor Lokasi Pengukuran Terhadap Tingkat Kebisingan (Studi Kasus: Jalan Demang Lebar Daun Kota Palembang). Sainmatika: Jurnal Ilmiah Matematika dan Ilmu Pengetahuan Alam, 15(1), 62-68.

Keputusan Menteri Lingkungan Hidup No. 48. 1996. Baku Mutu Kebisingan.

Ramli, M. I., Hustim, M., \& Ariani, U. (2014). Analisis Tingkat Kebisingan Pada Kawasan Perbelanjaan (Mall) di Kota Makassar Dan Dampaknya Terhadap Lingkungan. Jurnal Teknik Lingkungan Jurusan Sipil Fakultas Teknik Universitas Hasanuddin Makassar.

Wafiroh, A. H. (2013). Pengukuran Tingkat Kebisingan di Lingkungan SMPN 2 Jember. Skrpisi. Jurusan Fisika. Fakultas Matematika dan Ilmu Pengetahuan Alam. Universitas Jember. 